\title{
Advances in Eco-Efficient Agriculture: The Plant-Soil Mycobiome
}

\author{
Marcela Claudia Pagano ${ }^{1, *}$, Eduardo J. Azevedo Correa ${ }^{2}$, Neimar F. Duarte ${ }^{3}$, \\ Bakhytzhan Yelikbayev ${ }^{4}$, Anthonia O'Donovan ${ }^{5}$ and Vijai Kumar Gupta 6 \\ 1 Institute of Biological Sciences, Federal University of Minas Gerais, Av. Antônio Carlos, 6627, \\ 31270-901 Belo Horizonte, Brazil \\ 2 Empresa de Pesquisa Agropecuária de Minas Gerais, Campo Experimental de Pitangui, Caixa Postal 43, \\ CEP 35650-000 Pitangui, Brazil; eduardo@epamig.br \\ 3 Instituto Federal de Minas Gerais, 30421-169 Belo Horizonte, Brazil; neimar@ifmg.edu.br \\ 4 Kazakh National Agrarian University, 8 Abai st., 050010 Almaty, Kazakhstan; bek29k@gmail.com \\ 5 Department of Life and Physical Sciences, School of Science and Computing, Galway-Mayo Institute of \\ Technology, Dublin Road, H91 T8NW Galway, Ireland; toniodonovan@gmail.com \\ 6 Department of Chemistry and Biotechnology, ERA Chair of Green Chemistry, School of Science, \\ Tallinn University of Technology, 12618 Tallinn, Estonia; vijaifzd@gmail.com \\ * Correspondence: marpagano@gmail.com
}

Academic Editor: Yinglong Chen

Received: 10 November 2016; Accepted: 8 February 2017; Published: 15 February 2017

\begin{abstract}
In order to achieve a desirable ecological and sustainable agriculture a thorough understanding of the plant-soil mycobiome is imperative. Commercial industrial agriculture alters greenhouse gas emissions, promotes loss of plant and soil biodiversity, increases pollution by raising atmospheric $\mathrm{CO}_{2}$, and releases pesticides, thus affecting both terrestrial and aquatic ecosystems. Diversified farming systems, including perennial cultivated pastures, are among worldwide strategies that aim to reduce terrestrial greenhouse gas emissions and deal with threats to global sustainability. Additionally, stimulation of soil microbes and appropriate soil management can influence soil interactions as well as the rates of organic matter decomposition and the release of gases. Agricultural soil microbial communities play a central role in ecosystem processes and are affected by biocontrol agents, biofertilizers, and exposure to pesticides, the extent to which is yet to be fully elucidated. Intercropping different plant species is beneficial, as this can increase carbon fixation by plants, transferring carbon to the soil, especially via mycorrhizas, thus modifying interplant interactions. This review focuses on agro-ecosystems, showing the latest advances in the plant-soil interface (the mycobiome) for an eco-efficient agricultural production.
\end{abstract}

Keywords: plant-soil interaction; mycobiome; mycorrhizas; hyphosphere; eco-efficient agriculture

\section{Introduction}

Research on soil mycobiome [1], phytobiome, or plant microbiome is currently increasing along with increased interest on the mycorrhizosphere [2]. At the same time, generating further information to help navigate towards an ecological and more sustainable agriculture is the focus of academics, non-governmental associations, and farmers.

Attention to the fungal communities (mycobiomes) and information on environmental biodiversity is required for policy and decision makers [3]. New projects dealing with plant rhizosphere and the associated microbiota have been proposed, as most plants associate with microorganisms in a mutually beneficial way (symbiosis); for example, one plant species can host different species of endophytes and root symbionts, among other interactions [4]. Soil micro-organisms have diverse distribution patterns, 
and high biodiversity can be found in particular ecosystems [5], however, we do not understand yet the complexity of microorganisms present in these interactions and their roles, including the association between arbuscular mycorrhizas (AMs) hyphae, and soil microbiota, in the "Hyphosphere" (soil volume under direct influence of AM fungal hyphae) [6] (Figure 1). Soil micro-organisms have diverse distribution patterns, and that high biodiversity can be found in particular ecosystems [5]; however, understanding the processes underlying the plant microbial interactions both in natural and semi-natural ecosystems is of crucial importance [5].

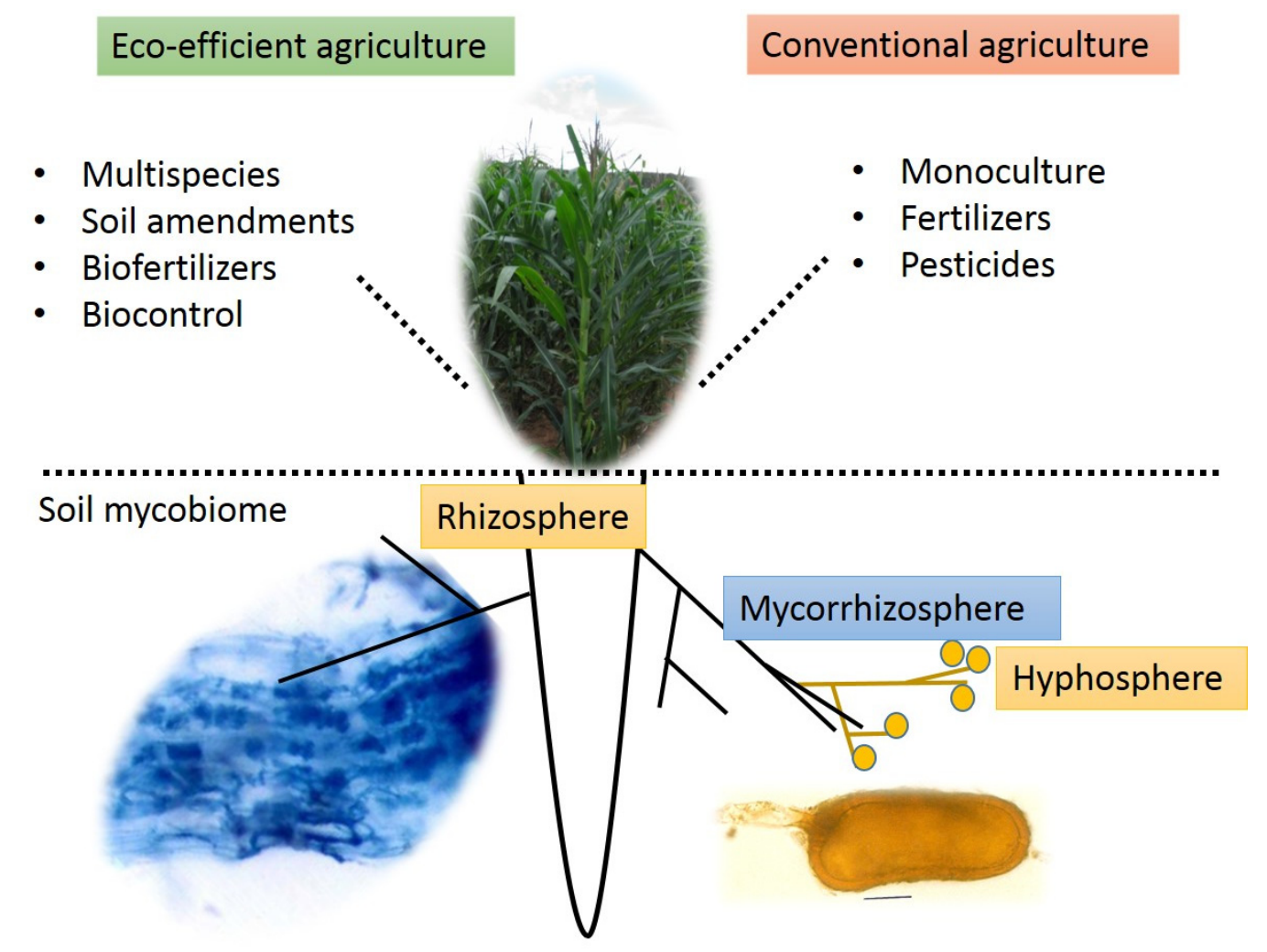

Figure 1. Schematic representation of the agriculture systems showing some characteristics and the different plant-soil compartments.

It is known that industrial agriculture and livestock alters greenhouse gas emissions, promotes loss of biodiversity, and increases pollution by fertilizers and pesticides, which can result in soil degradation [7]. Fortunately, increasing scientific research worldwide points to the preference for the establishment of more ecological sustainable farming systems $[7,8]$. Thus, linking microbial ecological interactions to global nutrient cycling, chemical pollution, green-house gas emissions, carbon (C) and nitrogen $(\mathrm{N})$ management in natural or managed ecosystems within the context of global biodiversity alterations, and microbial diversity loss, is needed [5].

This review shows how eco-efficient agricultural production can be improved by increasing use of biofertilizers and biocontrol agents, adopting perennial cultivation practices, and decreasing greenhouse gas emissions. Types of agro-ecosystems to mitigate global change constraints and projects including diversified farming systems with an emphasis on agroecology are discussed.

\section{The Soil Mycobiome}

The soil mycobiome [1] has been discussed by several reports, most of them dedicated to investigating the phytobiome or rhizosphere (Figure 1). However, the fungal communities (mycobiomes) constituting a large portion of the soil microbes are central in maintaining soil processes, which finally affect the functioning of terrestrial ecosystems. 
Most soil fungi are endemic to particular bioregions, suggesting that factors operating at large spatial scales, like dispersal limitation or climate, are the first-order determinants of fungal community structure in nature [1]. Soil micro-organisms display diverse distribution patterns [6] and high biodiversity can be found in particular ecosystems, as different habitat types (tropical forests, temperate forests and anthropogenic ecosystems) can sustain diverse fungal communities.

In organic orchards of semi-arid lands [9], and artificial grasslands and cultivated areas [10], the occurrence and diversity of arbuscular mycorrhizal fungi, which are considered significant biofertilizers (see next section), is an important outcome. Moreover, several arbuscular mycorrhizal fungi show a global distribution (Glomus intraradices/fasciculatum group, G. mosseae, G. hoi, as well as the Glomus and Scutellospora [8]).

\section{The Plant-Soil Mycobiome}

Additional environmental information on climate change, natural resource depletion, biodiversity loss, and environmental health is required for policy and decision makers [3]. New projects dealing with plant rhizosphere are progressively being proposed and thus, the number of reports on this topic is increasing (Table 1). One of them, by F. Buscot in Germany, deals with multitrophic interactions of oak [11] and aims to show how the interactions impact the rhizospheric microbial community. Other projects intend to evaluate the ecological-economic integrity of soil cultivated with genetically modified crops (by P. H. Krogh, Aarhus University, for example).

Table 1. Journal articles dealing with symbiotic plant and soil mycobiome.

\begin{tabular}{ccc}
\hline Key Words & Total Number of Journal Articles & Number of Journal Articles/Period $^{+}$ \\
\hline Plant Microbiome & 822 & 742 \\
Mycosphere & 37 & 23 \\
Plant + Mycobiome & 13 & 12 \\
Phytobiome & 14 & 14 \\
Soil + Mycobiome & 5 & 5 \\
\hline
\end{tabular}

Database survey accessed at SCOPUS on January 2017. Period ${ }^{\dagger}$ : From 2013 to 2017.

Most plants associate with microorganisms in a mutually beneficial way (symbiosis): legumes associate with rhizobial bacteria, and legumes and non-legumes associate with other soil microorganisms, especially with fungi, such as arbuscular mycorrhizal fungi (AMF) (Glomeromycota), which are natural biofertilizers that constitute the mycorrhizosphere [2]. The saprophytic capability of ectomycorrhizas has been shown; however, for AMF, more detail is required to better understand their capacity to use organic N. Moreover, the "Nitrogen Paradox" suggested that N fertilization of AM plants is only beneficial if the plant is limited by $\mathrm{P}$ [12]. Moreover, $\mathrm{N}$ constraints can limit the promotion of plant biomass due to $\mathrm{CO}_{2}$ fertilization [13].

Mycorrhizas connect dissimilar environments: plant and the adjacent soil, participating in plant mineral nutrition, water acquisition, carbon distribution, tolerance to abiotic and biotic stresses, and interplant competition [14,15]. Recently, reports by Jansa et al. [14] questioned the hyphae-associated microbes and their functions in the soil-plant system. Some theories stress the occurrence of highly specialized microbial communities colonizing the surface of mycorrhizal hyphae in the soil, or that the specific associative microbes are rewarded by fungal carbon like "hypersymbionts" (i.e., symbionts of symbiotic mycorrhizal fungi). Hyphae-associated microbes can also release bioactive compounds, also suggesting some of the effects of plant-plant interactions, as the hyphal networks have been shown to transfer the allelopathic in the soil [16].

It is known that the mycorrhizal hyphae are influenced by soil prokaryotes, other fungi, protozoans, nematodes, and other organisms. Moreover, differences were observed in the associated soil microorganisms with regard to non-hyphospheric soils [16,17]. Jansa et al. [14] stressed that the existence of a specific 
microflora on the mycorrhizal hyphae or a specific hyphosphere remain mostly unclear and that those knowledge gaps need further investigation.

Other symbioses are present in legumes (rhizobia) or in actinorhizal plants such as Alnus sp., Casuarina sp. [18], and in some genus of Rosaceae (Cercocarpus, Chamaebatiaria, Dryas, Purshia) [19]. Actinorhizal plants can form root nodules in symbiosis with the nitrogen-fixing actinomycete Frankia, which permits plant succession after flooding or fires, and they have worldwide distribution [20,21]. This symbiosis is important for forestry and agroforestry purposes, as actinorhizal species can increase soil nitrogen content [22]; however, this symbiosis has been poorly studied. Moreover, some strains of Frankia can proliferate in the litter, being potential saprophytic [23]. Frankia symbionts are filamentous, gram-positive, N-fixing bacteria. Frankia was found to be associated with 25 genera of host plants (eight families) comprising more than 220 species [24,25].

Frankia have been classified in three groups based on the host plant family [25]:

i Alnus (Betulaceae)/Myricaceae/Casuarinaceae group,

ii Eleagnaceae/Rhamnaceae group,

iii Frankia symbiotic with actinorhizal plants (Coriariaceae, Datiscaceae, and Rosaceae) and the genus Ceanothus (Rhamnaceae)

Furthermore, Frankia strains within a single host group also exhibit some degree of genetic heterogeneity, yet the patterns and causes of this heterogeneity are less well understood [18] despite their great potential.

On the other hand, non-symbiotic microorganisms, the saprothrophic fungi, can benefit plants by playing different roles in the plant-soil compartment. Species of Trichoderma are among the natural biocontrol agents, also included in commercial biofungicides [26], biofertilizers, and soil amendments [27]. Trichoderma is cosmopolitan and predominant in different ecosystems in a wide range of climatic regions. Moreover, these versatile fungi can be theoretically isolated from different agricultural fields. The species occurrence is controlled by several factors including microclimate, the availability of substrates, and intricate ecological interactions. The rhizospheric soil is frequently its ecological niche, as the presence of other soil fungi that can be their prey and rich plant root derived material is also influential [28]; however, it can also be isolated from artificial substrata, with the presence of xenobiotics. Some species occur as plant-endophytes, promoting plant growth, decreasing drought stress effects, and preventing plants against diseases [29].

Regarding conservation agricultural practices, it is known that soil organic carbon (SOC) distribution is affected along the soil profile. Maintenance of crop residues on the soil surface (non-tillage) and root $\mathrm{C}$ input can promote SOC accumulation in the $0-30 \mathrm{~cm}$ of the soil profile. Thus, $\mathrm{C}$ content and quality in the top layers model the vertical distribution of soil organic carbon depending on the local soil conditions [30]. Perennial cultivation practices also contribute to carbon fixation and soil organic matter content (higher soil C sequestration), being part of the strategy for reducing terrestrial greenhouse gas emissions worldwide.

Regarding leaf-inhabiting mycobiome diversity, some studies have compared plant-associated fungal communities (mycobiomes) in diverse habitats and under different climates. In this sense, Unterseher et al. [31] observed differences between the plant-associated fungal communities (mycobiomes) from Fagus sylvatica from natural habitats and from a managed tree nursery. They found low mycobiome diversity in the artificial habitat (nursery). This pointed towards a pronounced importance of local conditions for the structure of plant mycobiomes and for a close interrelation of phyllosphere fungi and leaf physiology [31].

\section{The Mycobiome in Anthropogenic Soils}

On-farm biopurification systems [32] or farm management practices such as biofertilization [33] are increasingly studied to help minimize agricultural contamination and for sustainable production. Several toxic compounds (pesticides and other substances) from polluted wastewater sources generated 
in the farmyard can affect the associated microbiomes [34]. Martini et al. [35] showed a high proportion of bacteria tolerant to antibiotics or heavy metals, isolated from on-farm biopurification systems (biofilters) used for pesticide removal from wastewater in intensive agricultural systems.

Anthropogenic compounds have an effect on microbial communities, soil microbial diversity, and can also affect some biochemical reactions. Hussain et al. [36] compiled information on negative (most reported) and positive (less reported) effects of applied pesticides on soil health. Among them, a decrease in abundance of beneficial soil microorganisms and their biotransformation in the soil, inactivation of nitrogen-fixing and phosphorus solubilizing microorganisms, and a decreased biological nitrogen fixation, were reported.

In agro-ecosystems, the influence of organic versus conventional farming strongly influences the value of soil microbiological activity. Organic farming can modify the structure, richness, evenness, and dispersion of the soil microbiota when compared with managed soils under mineral fertilization (See Fließbach et al. 2007) [37].

Some positive effects of applied pesticides on soil health were also reported, such as herbicides (Glyphosate) that increase fungal activity [38] or increased organic matter (and consequent microbial activity) due to fungicides. Imfeld and Vuilleumier [39] reviewed the responses of the soil bacteria to pesticide exposure in agricultural soils; however, they concluded that the understanding of the bacterial community composition and dynamics, and its roles for ecosystem processes, in the context of introducing pesticide mixtures, is still insufficient.

The use of prepared on-farm AMF inoculum can increase plant yield with minimal change in farm management even in a high P soil [33]. Biomixtures (biobed organic substrate, active part of biopurification systems) were also bioaugmented with degrading ligninolytic fungi in a composition of 50:25:25 (lignocellulosic substrate:humic component:soil), but the formulation will depend on the target pesticide to obtain their optimal performance [32].

The increased chemical inputs and deleterious effects on the soil ecosystem are not completely studied. We know that toxic chemicals and different plant physiological disorders of current monoculture destroys the wild ecosystem [40]. However, the effect of manures, wastes, residues, compost, and biochar amendments to the soil system is increasingly studied worldwide, as organic systems are more profitable.

The adoption of natural soil conditioners by commercial agriculture is slowly increasing, but organic agriculture has rapidly adopted the addition of natural residues on horticultural plants and crops, and compatibility among biofertilizers and soil conditioners. To support sustainable agricultural systems and to deal with the effects of global change, the associated plant-soil microbial communities need detailed assessment.

The mycorrhizal symbiosis, application of compost (selected urban waste) [41], efficient phosphate solubilizing microorganisms [42], microbial inoculants, and biochar [43] as well as other soil conditioners (See Kumar [44]) for crops and agroforestry practices are increasingly being investigated worldwide.

Some agroecosystems that have more economic interest such as coffee, olive, and vineyards, including their associated microbiota, are the focus of new technologies for cultivation.

To study the microbiome in crops, the effects of different soil conditioners, and their agricultural implications on agronomical successions and organic matter decomposition, needs to be understood.

Moreover, ectomycorrhizal plants can model associated symbiotic fungal communities according to anthropogenic disturbance or climate change by modifying interplant interactions. Potential impacts on the establishment and growth of seedlings dependent on interplant transfer of hydraulically redistributed water via mycorrhizal hyphal networks linking the roots of neighboring plants will be crucial for plant survival during drought periods. Different fungal species (drought-sensitive hydrophilic or drought-tolerant hydrophobic) can have different effects on hydraulic redistribution patterns. This was shown for Mediterranean pine woodlands with climate change-induced alteration of ectomycorrhizal fungi (EMF) abundance and community composition increasing dominance of hydrophobic EMF relative to hydrophilic EMF with climate warming and drying [45]. 


\section{Latest Advancements in the Mycobiome of Tropical Agro-Ecosystems}

Commercial industrial agriculture alters greenhouse gas emissions, promotes loss of biodiversity, and increases pollution including atmospheric $\mathrm{CO}_{2}$. Increased plant photosynthetic activity and improved $C$ fixation by plants can transfer more $C$ to the soil via mycorrhizas. However, stimulation of other soil microbes and appropriate soil management (soil $\mathrm{N}$ and organic matter quality) can influence soil decomposition. Increasingly use of perennial cultivated pastures contributes to carbon fixation, soil organic matter content (higher soil C sequestration), and can decrease greenhouse gas emissions. Types of agro-ecosystems to mitigate climate change constrains and projects including diversified farming systems with an emphasis on agroecology are among worldwide strategies for reducing terrestrial greenhouse gas emissions.

Management of vulnerable areas in South Asia and Africa cultivated with maize and wheat, for example, were reformulated for sustainable food production with "conservation agriculture" [46]. In Latin America, increasing interest in $C$ sequestration points to better management in pasture systems. International projects such as "Carbon Sequestration Project, The Netherlands Cooperation CO-01002" on soil C sequestration in pastures and forest-pastoral systems, promote these studies [47].

In South America, integrating cropping livestock systems reduces irrigation and energy needs in comparison to monoculture; however, there is insufficient scientific information to optimize agroforestry adoption [48]. Moreover, pastures with intercropped grasses and legumes can increase the production, the forage quality, and the profitability and sustainability of these systems in tropical regions [49]. Species of Brachiaria and Panicum are mainly included in tropical agro-systems [50]. Tropical pastures such as Urochloa decumbens syn. Brachiaria decumbens Stapf under no-till cultivation, are commonly used due to its adaptation and large root system ( $2 \mathrm{~m}$ depth). Thus, substantial amounts of straw can be deposited on the ground in addition to a greater amount of root decomposition, which allows for a network in the soil for gas exchange, and for water infiltration [51].

If given due consideration, modern crop system designs providing multiple environmental benefits [52] could play a pivotal role in the conservation of agro-ecosystems, especially under predicted climate change scenarios. The objective of this review was to evaluate the advancements in tropical agro-ecosystem management, under climate change constraints in tropical regions.

Information on the impacts of climate change on forest management is being increasingly accumulated; however, more actions are necessary to guarantee forest goods and services to mitigate impacts on forest management [53]. Recently, Federici et al. [54] showed that $\mathrm{CO}_{2}$ emissions from forests have decreased significantly, especially in Brazil. Many of the current greenhouse gas emissions (>30 percent) arise from the land use segment, and the reduction of emissions from agriculture, forestry, and other land uses is urgently needed as $C$ sequestration may provide large-scale removal of greenhouse gases from the atmosphere, through plant photosynthesis [55]. In this context, the study authors pointed out five major strategies for reducing terrestrial greenhouse gas emissions: enriching soil C, farming with perennials, climate-friendly livestock production, protecting natural habitats, and restoring degraded watersheds and rangelands. As an example, Eucalyptus and other fast-growing trees can fix $0.26 \mathrm{t}$ eq. carbon $/ \mathrm{m}^{3}$ of wood in a seven-year cycle, and thus, 500 trees per hectare in integrated crop-livestock-forest systems managed for wood production, cut in the tenth year, could fix 3.71 t eq. C [56,57].

The effect of abiotic environmental factors (temperature, humidity, light, water supply, nutrients, and $\mathrm{CO}_{2}$ ) vary with their intensity and determine plant growth, and increasingly represents a research topic of importance nowadays for climate change effects mitigation. Climate change is likely to have a significant impact on soil moisture and temperature conditions [58,59]. It is known that plants under climate change can respond in the following ways: tolerate, evolve, disperse, or die. Plant species may simply tolerate new conditions and persist; however, trees cannot rapidly evolve to cope with climate changes (generation times are usually long) (Reviewed by Booth et al.) [60].

In hot and humid conditions, the amount of precipitation is enough for the growth of plants, even if it primarily occurs through seasonal rain events, as is the case in some regions with 
precipitations of 1000-2000 mm per year. In savannah regions, such as the Cerrado vegetation in Brazil, where rains are seasonal, concern for water conservation should be greater. As it rains only part of the year, the planned distribution of trees even more strongly favor conditions that allow the largest possible amount of water to infiltrate and not wash away the soil surface, initiating erosion [61].

\section{Redesigning Agro-Ecosystems for Sustainability}

The most important vegetation parameter for soil erosion control as well as provisioning of plant products, invasion resistance, pathogen and pest regulation, soil fertility regulation [62], and interaction with communities of microorganisms [63], is plant cover. Moreover, better appreciation of the phytomicrobiome [64,65] will help in increasing the understanding of crop cycles [66]. Knowing the mycotrophic status of plant species is an important piece of information for plant cultivation, ecological restoration, and for screening for plant stress tolerance. AMF are considered to be of great importance for improving the mineral nutrition of the colonized plants, as their hyphae can access microsites [14,15]. Currently, circa 3617 plant species associate with AM [67]; however, it is estimated that 200,000 plant species could harbor this symbiosis [68]. The number of reports is continuously increasing. In 2012, 3941 colonized species were compiled [69]. These plant-microbe strategies can result in a better stress-alleviation [49]; however, the study of AMF contribution in agro-systems such as integrated crop-livestock agroecosystems is scarce [70]. The decrease in soil quality and in the observed AMF populations, as well as increased diseases and invasive species observed in conventional agro-ecosystems [71], has led to urgent examination of integrated cropping-livestock systems mainly for research [72] being essential for quantifying the potential advantages of mixed systems, and atmospheric $\mathrm{C}$ mitigation capacity.

The integrated agro-ecosystems can improve water retention and water quality despite climate change mitigation [73]. There is a lack of studies on different soil depths. In general, the studied soil depth is specified in each reported paper. In most cases the sampled depth is superficial. It is known that the root system of pastures can reach $2 \mathrm{~m}$ or more, which has important implications on soil and crops to be cultivated in the future. Thus, roots grow more, leaving more residues in the soil profile (dead roots) and in the surface (mulch) [59].

The literature highlights a variety of crops and vegetation which are useful for integrated crop-livestock systems. The choice of agroforestry tree species would have great implications for the occurrence of AMs, ecosystem services, and soil fertility; however, the use of different plants species and technologies needs more study [46,59]. Legumes are of particular interest, and several tree legumes have been tested in integrated tree-livestock systems, such as Leucaena leucocephala, Gliricidia sepium, Prosopis juliflora, Cratylia argentea, and Mimosa caesalpiinifolia [74].

Continuous improvements are essential to achieve more sustainable agro-ecosystems, as well as to improve pastures, especially in Brazil, an agricultural country [50]. To date, forage breeding programs have contributed to the development of improved pastures and cultivars of Brachiaria brizantha, Brachiaria decumbens, Brachiaria humidicola, and Panicum maximum (main pastures used in Brazil). In addition to this, commercial crops such as soybeans, maize, or beans can be cultivated between rows of forest trees for the first two or three years after the trees have been planted allowing cultivation of maize or sorghum, and subsequently the established pasture between the tree rows is grazed by cattle until the trees are harvested [75]. One approach is to grow Brachiaria sp. and Eucalyptus sp. Integrated crop-livestock systems can promote synergy between agricultural production and environmental quality mimicking the reality and diversity of natural rural systems $[51,53]$. In this context, the mycorrhizal fungi are crucial contributors of the phytomicrobiome (the complex plant associations with microbial communities [76]), and interactions with plant roots are also of importance in the rhizomicrobiome $[64,66,77]$.

Recently, there has been much greater interest in the use of different microbial species and strains of rhizobacteria and fungi, including Trichoderma, Piriformospora, and nonpathogenic Fusarium oxysporum to promote plant growth and to protect plants from stress [78]. Thus, the importance of developing 
strategies that re-shape the rhizospheric microbiome for biofertilization, and the importance of root growth stimulation, antibiosis, induced plant systemic resistance, parasitism, and rhizoremediation is nowadays recognized [78].

Thus, projects with an emphasis on agroecology, especially for systems-based research in biologically diversified farming and ranching systems, are considered to be of high importance. The use of soil amendments, such as biochar and compost, in combination with Brachiaria pastures is promising. Further studies evaluating the types of plant biostimulants based on multispecies consortia may address a better understanding of the phytomicrobiome, and bring sustainable, consortia-based products to sustainable agriculture.

\section{Conclusions}

This review was undertaken to explore the current information on tropical agro-ecosystem management with regard to the plant-soil mycobiome, and also focused on climate change constraints. Thus, relevant findings related to the benefits of plant-phytobiome management by increasing productivity or stress tolerance, mostly in South America, were highlighted. Accordingly, research paths necessary for the increased understating of ecosystem function, such as AMF occurrence and benefits, were presented.

Finally, the evidence presented here emphasizes the need to consider the use of symbiotic fungi for management practices in the environments that they are normally found. The choice of vegetal species would therefore have great implication in the manipulation of agro-ecosystems. Importantly, increasing appreciation that most agro-ecosystems need better management has deep consequences for climate mitigation.

Acknowledgments: Marcela Claudia Pagano is grateful to the Council for the Development of Higher Education at Graduate Level (CAPES), FAPEMIG, and Cnpq, Brazil, and to Erasmus Mundus, University of Porto and Lund University, Sweden (2016), for Post-doctoral scholarships granted.

Author Contributions: M.C.P. developed the idea for the review. The manuscript was written by M.C.P. with contributions from all the authors.

Conflicts of Interest: The authors declare no conflict of interest.

\section{Abbreviation}

$\begin{array}{ll}\text { AM } & \text { Arbuscular mycorrhizas } \\ \text { AMF } & \text { Arbuscular mycorrhizal fungi } \\ \text { EMF } & \text { Ectomycorrhizal fungi } \\ \text { SOC } & \text { Soil organic carbon }\end{array}$

\section{References}

1. Talbot, J.M.; Bruns, T.D.; Taylor, J.W.; Smith, D.P.; Branco, S.; Glassman, S.I.; Erlandson, S.; Vilgalys, R.; Liao, H.L.; Smith, M.E.; et al. Endemism and functional convergence across the North American soil mycobiome. Proc. Natl. Acad. Sci. USA 2014, 111, 6341-6346. [CrossRef] [PubMed]

2. Azcón, R. Mycorrhizosphere: The role of PGPR. In Root Engineering; Morte, A., Varma, A., Eds.; Springer: Berlin, Germany, 2014; pp. 107-144.

3. Specht, A.; Guru, S.; Houghton, L.; Keniger, L.; Driver, P.; Ritchie, E.G.; Lai, K.; Treloar, A. Data management challenges in analysis and synthesis in the ecosystem sciences. Sci. Total Environ. 2015, 534, $144-158$. [CrossRef] [PubMed]

4. Balestrini, R.; Lumini, E.; Borriello, R.; Bianciotto, V. Plant-Soil Biota Interactions. In Soil Microbiology, Ecology, and Biochemistry; Paul, E.A., Ed.; Elsevier: Amsterdam, The Netherlands, 2015; pp. 311-329.

5. Saleem, M.; Moe, L.A. Multitrophic microbial interactions for eco- and agro-biotechnological processes: Theory and practice. Trends Biotechnol. 2014, 32, 529-537. [CrossRef] [PubMed] 
6. Jansa, J.; Gryndler, M. Biotic environment of the arbuscular mycorrhizal fungi in soil. In Arbuscular Mycorrhizas: Physiology and Function; Koltaiand, H., Kapulnik, Y., Eds.; Springer: Heidelberg, Germany, 2010; pp. 209-236.

7. DeLonge, M.S.; Miles, A.; Car, L. Investing in the transition to sustainable agriculture. Environ. Sci. Policy 2016, 55, 266-273. [CrossRef]

8. Pagano, M.C.; Dantas, B.D.; Weber, O.B.; Correa, E.A.; Tancredi, F.D.; Duarte, N.F.; Bago, A.; Cabello, M.N. Mycorrhizas in Agroecosystems. In Recent Advances on Mycorrhizal Fungi; Pagano, M.C., Ed.; Springer: Basel, Switzerland, 2016; pp. 91-100.

9. Dantas, B.L.; Weber, O.B.; Neto, J.P.M.; Rossetti, A.G.; Pagano, M.C. Diversity of arbuscular mycorrhizal fungi in an organic orchard of semi-arid land of Ceará, Brazil. Cienc. Rural 2015, 45, 1480-1486. [CrossRef]

10. Azevedo, E.J.A.; Duarte, N.F.; Parreira, A.G.; Pagano, M.C. Biodiversidade de fungos micorrizicos na fazenda experimental de Pitangui-Minas Gerais: Potencialidades de aplicação na agricultura e restauração de áreas. In Proceedings of the II Simpósio de Microbiologia da UFMG, Belo Horizonte, Brazil, 5-6 October 2015.

11. Buscot, F. TrophinOak-Helmholtz Centre for Environmental Research UFZ in Halle. Available online: www.trophinoak.de (accessed on 23 January 2017).

12. Johnson, N.C. Resource stoichiometry elucidates the structure and function of arbuscular mycorrhizas across scales. New Phytol. 2010, 185, 631-647. [CrossRef] [PubMed]

13. Reich, P.B.; Hobbie, S.E. Decade-long soil nitrogen constraint on the $\mathrm{CO}_{2}$ fertilization of plant biomass. Nat. Clim. Chang. 2013, 3, 278-282. [CrossRef]

14. Jansa, J.; Bukovská, P.; Gryndler, M. Mycorrhizal hyphae as ecological niche for highly specialized hypersymbionts-Or just soil free-riders? Front. Plant Sci. 2013, 4, 134. [CrossRef] [PubMed]

15. Smith, S.E.; Read, D.J. Mycorrhizal Symbiosis, 3rd ed.; Academic Press: London, UK, 2008.

16. Barto, E.K.; Hilker, M.; Muller, F.; Mohney, B.K.; Weidenhamer, J.D.; Rillig, M.C. The fungal fast lane: Common mycorrhizal networks extend bioactive zones of allelochemicals in soils. PLoS ONE 2011, 6, e27195. [CrossRef] [PubMed]

17. Scheublin, T.R.; Sanders, I.R.; Keel, C.; VanDerMeer, J.R. Characterisation of microbial communities colonizing the hyphal surfaces of arbuscular mycorrhizal fungi. ISME J. 2010, 4, 752-763. [CrossRef] [PubMed]

18. Oakley, B.; North, M.; Franklin, J.F.; Hedlund, B.P.; Staley, J.T. Diversity and Distribution of Frankia Strains Symbiotic with Ceanothus in California. Appl. Environ. Microbiol. 2004, 70, 11. [CrossRef] [PubMed]

19. Judd, W.S.; Campbell, C.S.; Kellogg, E.A.; Stevens, P.F.; Donoghue, M.J. Plant Systematics: A Phylogenetic Approach; Sinauer Associates: Sunderland, MA, USA, 2009.

20. Schwintzer, C.R.; Tjepkema, J.D. The Biology of Frankia and Actinorhizal Plants; Academic Press, Inc.: San Diego, CA, USA, 1990.

21. Stacey, G.; Burris, R.H.; Evans, H.J. Biological Nitrogen Fixation; Chapman and Hall: New York, NY, USA, 1992.

22. Babur, S.M.; Welsh, A.; Hahn, D. Saprophytic growth of inoculated Frankia sp. in soil microcosms. FEMS Microbiol. Ecol. 2007, 62, 280-289.

23. Baker, D.D.; Mullin, B.C. Actinorhizal symbioses. In Biological Nitrogen Fixation; Stacey, G., Burris, R.H., Evans, H.J., Eds.; Chapman and Hall: New York, NY, USA, 1992; pp. 259-292.

24. Wall, L.G. The Actinorhizal Symbiosis. J. Plant Growth Regul. 2000, 19, 167-182. [PubMed]

25. Clawson, M.L.; Benson, D.R. Natural diversity of Frankia strains in actinorhizal root nodules from promiscuous hosts in the family Myricaceae. Appl. Environ. Microbiol. 1999, 65, 4521-4527. [PubMed]

26. Harman, G.E.; Howell, C.R.; Viterbo, A.; Chet, I.; Lorito, M. Trichoderma species-Opportunistic, avirulent plant symbionts. Nat. Rev. Microbiol. 2004, 2, 43-56. [CrossRef]

27. Vinale, F.; Sivasithamparam, K.; Ghisalberti, E.L.; Marra, R.; Woo, S.L.; Lorito, M. Trichoderma-plant-pathogen interactions. Soil Biol. Biochem. 2008, 40, 1-10. [CrossRef]

28. Kredics, L.; Hatvani, L.; Naeimi, S.; Körmöczi, P.; Manczinger, L.; Vágvölgyi, C.; Druzhinina, I. Biodiversity of the Genus Hypocrea/Trichoderma in Different Habitats. In Biotechnology and Biology of Trichoderma; Gupta, V.G., Schmoll, M., Herrera-Estrella, A., Upadhyay, R.S., Druzhinina, I., Tuohy, M., Eds.; Elsevier: Amsterdam, The Netherlands, 2014; pp. 3-24.

29. Gupta, V.K.; Schmoll, M.; Herrera-Estrella, A.; Upadhyay, R.S.; Druzhinina, I.; Tuohy, M.G. Biotechnology and Biology of Trichoderma; Gupta, V.G., Schmoll, M., Herrera-Estrella, A., Upadhyay, R.S., Druzhinina, I., Tuohy, M., Eds.; Elsevier: Amsterdam, The Netherlands, 2014. 
30. Piccoli, I.; Chiarini, F.; Carletti, P.; Furlan, L.; Lazzaro, B.; Nardi, S.; Berti, A.; Sartori, L.; Dalconi, M.C.; Morari, F. Disentangling the effects of conservation agriculture practices on the vertical distribution of soil organic carbon. Evidence of poor carbon sequestration in North-Eastern Italy. Agric. Ecosyst. Environ. 2016, 230, 68-78. [CrossRef]

31. Unterseher, M.; Siddique, A.B.; Brachmann, A.; Peršoh, D. Diversity and Composition of the Leaf Mycobiome of Beech (Fagus sylvatica) Are Affected by Local Habitat Conditions and Leaf Biochemistry. PLoS ONE 2016, 1, e0152878. [CrossRef] [PubMed]

32. Ruiz-Hidalgo, K.; Chin-Pampillo, J.S.; Masís-Mora, M.; Carazo-Rojas, E.; Rodríguez-Rodríguez, C.E. Optimization of a Fungally Bioaugmented Biomixture for Carbofuran Removal in On-Farm Biopurification Systems. Water Air Soil Pollut. 2016. [CrossRef]

33. Douds, D.D., Jr.; Lee, J.; McKeever, L.; Ziegler-Ulsh, C.; Ganser, S. Utilization of inoculum of AM fungi produced on-farm increases the yield of Solanum lycopersicum: A summary of 7 years of field trials on a conventional vegetable farm with high soil phosphorus. Sci. Hortic. 2016, 207, 89-96. [CrossRef]

34. Sniegowski, K.; Bers, K.; Ryckeboer, J.; Jaeken, P.; Spanoghe, P.; Springael, D. Robust Linuron Degradation in On-Farm Biopurification Systems Exposed to Sequential Environmental Changes. Appl. Environ. Microbiol. 2011, 77, 6614-6621. [CrossRef] [PubMed]

35. Martini, M.C.; Albicoro, F.J.; Nour, E.; Schlüter, A.; van Elsas, J.D.; Springael, D.; Smalla, K.; Pistorio, M.; Lagares, A.; Del Papa, M.F. Characterization of a collection of plasmid-containing bacteria isolated from an on-farm biopurification system used for pesticide removal. Plasmid 2015, 80, 16-23. [CrossRef] [PubMed]

36. Hussain, S.; Siddique, T.; Saleem, M.; Arshad, M.; Khalid, A. Impact of pesticides on soil microbial diversity, enzymes, and biochemical reactions. Adv. Agron. 2009, 102, 159-200.

37. Fließbach, A.; Oberholzer, H.-R.; Gunst, L.; Mäder, P. Soil organic matter and biological soil quality indicators after 21 years of organic and conventional farming. Agric. Ecosyst. Environ. 2007, 118, 273-284. [CrossRef]

38. Araujo, A.S.F.; Monteiro, R.T.R.; Abarkeli, R.B. Effect of glyphosate on the microbial activity of two Brazilian soils. Chemosphere 2003, 52, 799-804. [CrossRef]

39. Imfeld, G.; Vuilleumier, S. Measuring the effects of pesticides on bacterial communities in soil: A critical review. Eur. J. Soil Biol. 2012, 49, 22-30. [CrossRef]

40. Altieri, M.A. Agroecological foundations of alternative agriculture in California. Agric. Ecosyst. Environ. 1992, 39, 23-53. [CrossRef]

41. Viti, C.; Tatti, E.; Decorosi, F.; Lista, E.; Rea, E.; Tullio, M.; Sparvoli, E.; Giovannetti, L. Compost Effect on Plant Growth-Promoting Rhizobacteria and Mycorrhizal Fungi Population in Maize Cultivations. Compost Sci. Util. 2010, 4, 273-281. [CrossRef]

42. Pagano, M.C.; Covacevich, F. Arbuscular Mycorrhizas in Agroecosystems. In Mycorrhizal Fungi: Soil, Agriculture and Environmental Implications; Fulton, S.M., Ed.; Nova Science Publishers: New York, NY, USA, 2011; pp. 35-65.

43. Pagano, M.C.; Jorio, A. The contributions of mycorrhizal fungi. In Microbial Bioresources; Gupta, V.K., Sharma, G.D., Tuohy, M.G., Gaur, R., Eds.; CABI: London, UK, 2016; pp. 14-28.

44. Kumar, V. Use of Integrated Nutrient Management to Enhance Soil Fertility and Crop Yield of Hybrid Cultivar of Brinjal (Solanum melongena L.) Under Field Conditions. Adv. Plants Agric. Res. 2016, 4, 00130. [CrossRef]

45. Prieto, I.; Roldán, A.; Huygens, D.; Alguacil, M.M.; Navarro-Cano, J.A.; Querejeta, J.I. Species-specific roles of ectomycorrhizal fungi in facilitating interplant transfer of hydraulically redistributed water between Pinus halepensis saplings and seedlings. Plant Soil 2016, 406, 15-27. [CrossRef]

46. Powlson, D.S.; Stirling, C.M.; Thierfelder, C.; White, R.P.; Jate, M.L. Does conservation agriculture deliver climate change mitigation through soil carbon sequestration in tropical agro-ecosystems? Agric. Ecosyst. Environ. 2016, 220, 164-174. [CrossRef]

47. Amézquita, M.C.; Ibrahim, M.; Llanderal, T.; Buurman, P.; Amézquita, E. Carbon Sequestration in Pastures, Silvo-Pastoral Systems and Forests in Four Regions of the Latin American Tropics. J. Sustain. For. 2004, 21, 31-49. [CrossRef]

48. Pagano, M.C.; Cabello, M.N. Mycorrhizal Interactions for Reforestation: Constraints to Dryland Agroforest in Brazil. ISRN Ecol. 2011, 2011, 890850. [CrossRef]

49. Resende, A.S.; Xavier, R.P.; Quesada, D.M.; Urquiaga, S.; Alves, B.J.R.; Boddey, R.M. Use of green manures in increase inputs of biological nitrogen fixation to sugar cane. Biol. Fert. Soils 2003, 37, 215-220. 
50. Jank, L.; Barrios, S.C.; do Valle, C.B.; Simeão, R.M.; Alves, G.F. The value of improved pastures to Brazilian beef production. Crop Pasture Sci. 2014, 65, 1132-1137. [CrossRef]

51. Alvarenga, R.C.; Noce, M.A. Integração Lavoura-Pecuária; Embrapa Milho e Sorgo: Sete Lagoas, Brazil, $2005 ;$ p. 16.

52. Lemaire, G.; Franzluebbers, A.; Carvalho, P.C.F.; Dedieu, B. Integrated crop-livestock systems: Strategies to achieve synergy between agricultural production and environmental quality. Agric. Ecosyst. Environ. 2014, 190, 4-8. [CrossRef]

53. Nelson, H.W.; Williamson, T.B.; Macaulay, C.; Mahony, C. Assessing the potential for forest management practitioner participation in climate change adaptation. For. Ecol. Manag. 2016, 360, 388-399. [CrossRef]

54. Federici, S.; Tubiello, F.N.; Salvatore, M.; Jacobs, H.; Schmidhuber, J. New estimates of $\mathrm{CO}_{2}$ forest emissions and removals: 1990-2015. For. Ecol. Manag. 2015, 352, 89-98. [CrossRef]

55. Scherr, S.J.; Sthapit, S. Mitigating climate change through food and land use. Worldwatch Pap. 2009, 179, 1-49.

56. Ferreira, C.C.; Silva, H.D. Formação de Povoamentos Florestais; Embrapa Florestas: Colombo, Sri Lanka, 2008; p. 109.

57. Melotto, A.M.; Laura, V.A. Sistemas Silvipastoris para Bovinos e Ovinos; Embrapa Gado de Corte: Campo Grande, Brazil, 2009; p. 36.

58. IPCC. Climate Change 2001: The Science of Climate Change; Cambridge University Press: Cambridge, UK, 2001.

59. Loaiciga, H.A.; Valdes, J.B.; Vogel, R.; Garvey, J.; Schwarz, H. Global warming and the hydrologic cycle. J. Hydrol. 1996, 174, 83-127. [CrossRef]

60. Booth, T.H.; Broadhurst, L.M.; Pinkard, E.; Prober, S.M.; Dillon, S.K.; Bush, D.; Pinyopusarerk, K.; Doran, J.C.; Ivkovich, M.; Young, A.G. Native forests and climate change: Lessons from eucalypts. For. Ecol. Manag. 2015, 347, 18-29. [CrossRef]

61. Alvarenga, R.C.; Porfirio-da-Silua, V.; Gontijo Neto, M.M.; Viana, M.C.M.; Vilela, L. Sistema Integração lavoura-Pecuária-Floresta: Condicionamento do solo e intensificação da produção de lavouras. Informe Agropecu. Belo Horizonte 2010, 31, 59-67.

62. Quijas, S.; Schmid, B.; Balvanera, P. Plant diversity enhances provision of ecosystem services: A new synthesis. Basic Appl. Ecol. 2010, 11, 582-593. [CrossRef]

63. Pagano, M.C.; Cabello, M.N. Arbuscular Mycorrhizas alleviate plant stress: Analysis of studies from South America. In Biotechnological Techniques of Stress Tolerance in Plants; Miransari, M., Ed.; Studium Press LLC: Houston, TX, USA, 2013; pp. 131-150.

64. Hirsch, P.R.; Mauchline, T.H. Who's who in the plant root microbiome? Nat. Biotechnol. 2012, 30, 961-962. [CrossRef] [PubMed]

65. Peiffer, J.A.; Spor, A.; Koren, O.; Jin, Z.; Tring, S.G.; Dangl, J.L.; Bucklera, E.S.; Ley, R.E. Diversity and heritability of the maize rhizosphere microbiome under field conditions. Proc. Natl. Acad. Sci. USA 2013, 16, 6548-6553. [CrossRef] [PubMed]

66. Smith, D.L.; Subramanian, S.; Lamont, J.R.; Bywater-Ekegärd, M. Signaling in the phytomicrobiome: Breadth and potential. Front. Plant Sci. 2015, 6, 709. [CrossRef] [PubMed]

67. Wang, B.; Qiu, Y.L. Phylogenetic distribution and evolution of mycorrhizas in land plants. Mycorrhiza 2006, 16, 299-363. [CrossRef] [PubMed]

68. Kuyper, T.W.; Goede, R.G.M. Interaction between higher plants and soil-dwelling organisms. In Vegetation Ecology; der Maarel, E., Ed.; Blackwell: Oxford, UK, 2005; pp. 286-308.

69. Pagano, M.C. (Ed.) Mycorrhiza: Occurrence and Role in Natural and Restored Environments; Nova Science Publishers: Hauppauge, NY, USA, 2012.

70. Davinic, M.; Moore-Kuceraa, J.; Acosta-Martínez, V.; Zak, J.; Allen, V. Soil fungal distribution and functionality as affected by grazing and vegetation components of integrated crop-livestock agroecosystems. Appl. Soil Ecol. 2013, 66, 61-70. [CrossRef]

71. Miranda, E.M.; Saggin Júnior, O.J.; da Silva, E.M.R. Selection of arbuscular mycorrhizal fungi for the forage peanut intercropped with signal grass. Pesq Agropec Bras 2008, 43, 9.

72. Martha Júnior, G.B.; Alves, E.; Contini, E. Dimensão econômica de sistemas de integração lavoura-pecuária. Pesq. Agropec. Bras. 2011, 46, 1117-1126. [CrossRef]

73. Balbino, L.C.; Cordeiro, L.A.M.; Oliveira, P.; Kluthcouski, J.; Galerani, P.R.; Vilela, L. Agricultura sustentável por meio da integração lavoura-pecuária-floresta. Inf. Agron. IPNI 2012, 138, 1-18. 
74. Dubeux, J.C.B., Jr.; Muir, J.P.; Ramachandran Nair, P.K.; Sollenberger, L.E.; Silva, H.M.S.; de Mello, A.C.L. The advantages and challenges of 3 integrating tree legumes into pastoral systems. In International Conference on Forages in Warm Climates, Proceedings of the 1st International Conference on Forages in Warm Climates, Lavras, Brazil, 1-3 June 2015; Evangelista, A.R., Avila, C.L.S., Casagrande, D.R., Lara, M.A.S., Bernardes, T.F., Eds.; University of Lavras: Lavras, Brazil, 2015; p. 393.

75. Pacheco, A.R.; De Chaves, R.Q.; Nicoli, C.M.L. Integration of Crops, Livestock, and Forestry: A System of Production for the Brazilian Cerrados. In Eco-Efficiency: From Vision to Reality; Hershey, C.H., Neate, P., Eds.; CIAT: Cali, Colombia, 2013; pp. 51-61.

76. Smith, D.L.; Zhou, X. An effective integrated research approach to study climate change in Canada. Can. J. Plant Sci. 2014, 94, 995-1008. [CrossRef]

77. Lundberg, D.S.; Lebeis, S.L.; Paredes, S.H.; Yourstone, S.; Gehring, J.; Malfatti, S.; Tremblay, J.; Engelbrektson, A.; Kunin, V.; del Rio, T.G.; et al. Defining the core Arabidopsis thaliana root. Nature 2012, 488, 86-90. [CrossRef] [PubMed]

78. Lugtenberg, B. (Ed.) Principles of Plant-Microbe Interactions. Microbes for Sustainable Agriculture; Springer: Basel, Switzerland, 2015.

(C) 2017 by the authors; licensee MDPI, Basel, Switzerland. This article is an open access article distributed under the terms and conditions of the Creative Commons Attribution (CC BY) license (http:/ / creativecommons.org/licenses/by/4.0/). 